\title{
DIE BETEKENIS WAT GELD VIR BLANKES EN KLEURLINGE INHOU
}

\author{
D.L. VISAGIE \\ DEPARTEMENT OPLEIDING \\ SOMCHEM EDMS. BPK.
}

\author{
I. VAN W. RAUBENHEIMER \\ DEPARTEMENT BEDRYFSIELKUNDE \\ UNIVERSITEIT VAN STELLENBOSCH
}

\begin{abstract}
SUMMARY
A survey of the literature indicates that money (which is an important concept in a number of theories of work

motivation) could mean different things to different people. Since this difference can be ascribed to early life experiences and personal factors, it could be expected that Coloureds and Whites would differ with respect to their evaluation of money. A semantic differential administered to 128 white and 109 coloured students, however, revealed no significant differences in general. The two groups differed significantly on only 2 of the 15 semantic scales.
\end{abstract}

Volkere en identiteitsgroepe binne dieselfde landsgrense verskil dikwels van mekaar in so verre dit norms, waardes, kulturele agtergrond en leefwyse betref.

In Suid-Afrika waar die burgersamestelling nie slegs veelvolkig en veeltalig is nie, maar ook veelrassig, gee dit regstreeks daartoe aanleiding dat werknemers in die meeste ondernemings saamgestel is uit verskillende min of meer homogene groepe, wat op 'n etniese en/of rasse grondslag gebaseer is.

'n Vraag wat die personeelkundige homself dikwels afvra, of wat topbestuur insae oor verlang, is tot welke mate die etniese- en rassesamestelling van werknemers in dieselfde onderneming ' $n$ invloed uitoefen op die werking van sekere motiveringsdeterminante. Meer spesifiek gestel, kom die vraag daarop neer of etniesiteit, as enkele faktor, nie sterk genoeg is om die betekenisse wat aan motiveringsdeterminante (bv. geld) geheg word tussen groepe te laat verskil nie. Hierdie vraag ontstaan n.a.v. die bevindings van studies wat daarop dui dat fundamentele verskille in betekenis van algemene begrippe tussen rasse- en etniese groepe voorkom (Allport, in Dyal, 1962 p.181; Segall, in Price-Williams, 1967; Feldsman, 1973, (a en b) en Orpen, 1975). 
Porter, Lawler en Hackman (1975, p.53) is verder van mening dat geld, soos ander motiveringsdeterminante in die werksituasie, vir elke individu 'n besondere betekenis inhou. Die "inhoud" van hierdie betekenis is gevolglik 'n belangrike bepaler van 'n werknemer se organisatoriese gedrag. Alhoewel personeelkundiges bewus is van die belangrikheid van geld en die betekenis daarvan berig Haire et al. $(1967,1)$ soos volg hieroor: "Pay is widely accepted as a prime motivator"; maar "There is relatively little data on the behavior of pay". Hier voeg Stull (1965, p.188) by dat die motiveringswaarde van geld helderder uitstaan indien die betekenis wat dit vir 'n persoon het, gepeil kan word.

Dit is interessant om op die bevindings van navorsingstudies, uitgevoer op verskillende rasse, te let wat oor geld as motiveringsdeterminant handel. Twee ondersoeke wat onder Kleurlingwerkers gedoen is toon aan dat geld 'n sterk motiveringsdeterminant is, terwyl Herzberg die teendeel beweer (Harris, 1973 en Van Eeden, 1974). Studies wat onder Bantoewerkers gedoen is toon ook aan dat geld ' $\mathrm{n}$ vername rol speel as motiveringsdeterminant (Orpen, 1974; Backer 1974 en Hewitt, 1976).

' $n$ Voor-die-hand-liggende verklaring vir hierdie navorsingsresultate is daar nie. Dit word verder bemoeilik as daarop gelet word dat sommige skrywers van mening is dat Blankes en Kleurlinge se optredes grotendeels op dieselfde waardesisteem berus (Cilliers, 1971, p.4) terwyl die milieu waarin die werkerstand van genoemde twee etniese groepe opgroei aansienlik verskil (op. cit., p.70). Om hierdie skynbare teenstrydighede in die regte perspektief te sien, is dit vir eers nodig om op die faktore te let wat die vorming van betekenisse beïnvloed.

Die vorming van betekenisse word deur verskeie persoonlike en agtergrondsfaktore beïnvloed. Die belangrikste persoonlike faktore wat hier ' $\mathrm{n}$ rol speel is die groeiproses (rypwording), leervermoë, waarnemingsvermoëns en so meer. Persoonlike faktore val egter buite die bestek van die artikel en sal nie verder op ingegaan word nie. Sosiale agtergrond en groepsnorme is besonder sterk bepalers van persoonlike waardes en betekenisse wat aan voorwerpe geheg word. Bruner en Goodman (Lindgren en Byrne, 1971, p.239) bevind byvoorbeeld dat kinders afkomstig uit relatief arm families geneig is om muntstukgroottes aansienlik te oorskat soos in figuur 1 aangedui. 


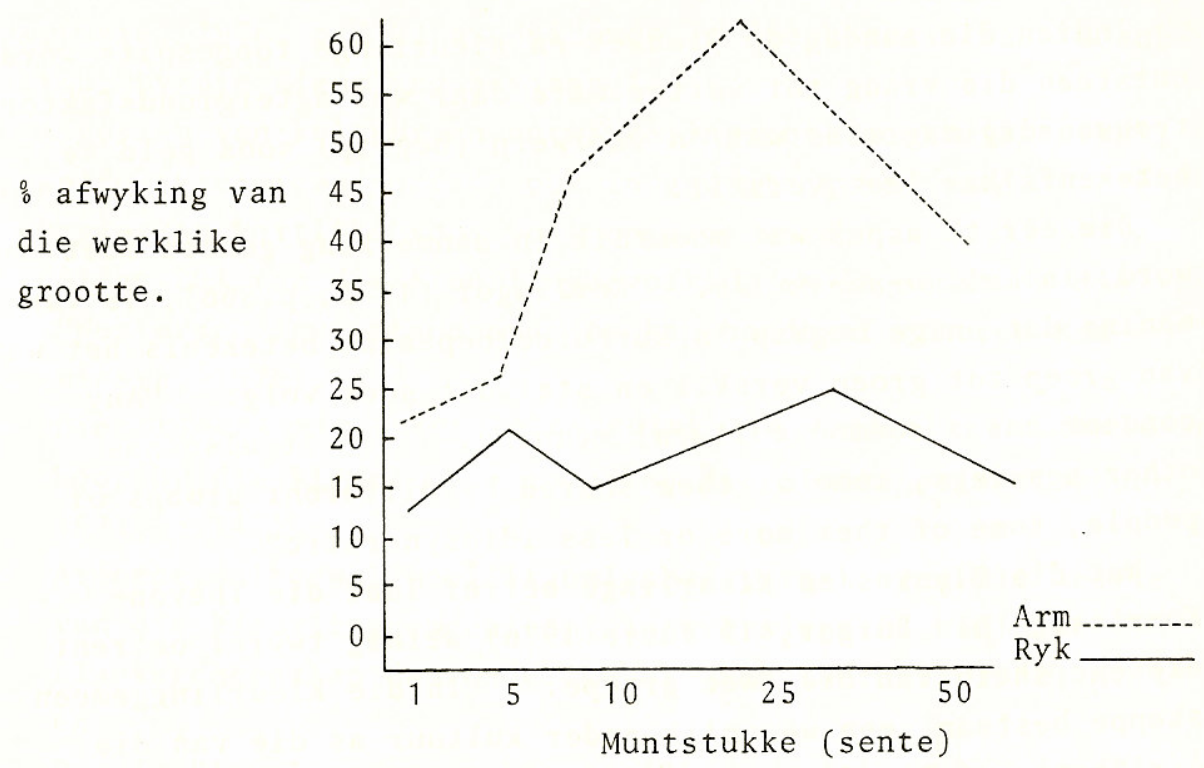

Figuur 1: Skattings van muntstukgroottes deur kinders afkomstig van arm en ryk families.

Die resultate soos in figuur 1 uitgebeeld kan ook beskou word as 'n voorbeeld van groepkonformering. Wanneer 'n individu by 'n groep inskakel of natuurlikerwys deel van die groep vorm, ontstaan die neiging om met die standaarde, norme en houdings van daardie groep te konformeer. Volgens Lindgren en Byrne (1971, p.51) is hierdie neiging tot konformiteit egter veral by etniese en rassegroepe ten opsigte van waardes en begrippe te bespeur. Binne sodanige groepe is daar dus tot ' $n$ groot mate ooreenstemming ten opsigte van die algemene betekenisse van voorwerpe en aspekte waarmee hulle in aanraking kom.

Indien die aandag op Blankes en Kleurlinge toegespits word, ontstaan die vraag tot watter mate daar wel agtergrondsfaktore teenwoordig mag wees wat 'n voorwerp (begrip) soos geld se betekenis kan laat verskil.

Die eerste aspek wat moontlik in aanmerking geneem moet word, is kultuurverskille. Kerlinger (1973, p.566), is van mening dat enige begrip 'n kultureel bepaalde betekenis het wat van groep tot groep verskil en stel dit soos volg: "Any concept has a common cultural meaning. It also has other meanings, some of them shared by different groups of people, some of them more or less idiosyncratic". 
Wat die Blankes en Kleurlinge betref laat die Theron-Kommissie (Die Burger, 19 Junie 1976) weinig twyfel omtrent die enersheid van die twee groepe. "In die Kleurlinggemeenskappe bestaan geen wesenlik ander kultuur as dié van die Afrikaans- of Engelssprekende Blankes nie".

Alhoewel dit dus aanvaar mag word dat daar kulturele ooreenkomste by die Blanke en Kleurling voorkom, is daar gewis ontwikkelingsverskille tussen die twee groepe. Hieromtrent druk Strauss (in Van der Walt, et al. 1967, p.93) hom soos volg uit: "Hoewel die Kleurlinge ten opsigte van hul kultuur en algemene leefwyse baie naby aan die Blankes staan, het hulle as gemeenskap egter nog lank nie dieselfde peil van sosiale, ekonomiese, opvoedkundige en algemene ontwikkeling van die Blankes bereik nie". (Dit moet daarop gewys word dat hierdie stelling reeds meer as 'n dekade oud is en dat die posisie vandag ietwat anders daaruit sien.)

Die verskil in ontwikkelingspeil tussen die twee groepe word ook soms verkeerdelik volgens Van der Ross (Theron-Kommissie, 1976, p.472) as duidende op die bestaan van 'n sub-kultuur by die Kleurling bestempel.

Afgesien van kultuur en ontwikkelingspeil moet die verskil in sosio-ekonomiese posisie ook in gedagte gehou word. Die situasie kan kortliks soos volg opgesom word:

- $\quad$ Slegs $20 \%$ van die Kleurlingbevolking is in staat om die "Westerse" lewenstandaarde te kan handhaaf (Theron-Kommissie, 1976).

- $\quad$ Die persentasie inkomstebesteding aan voedsel is dubbeld so hoog by die Kleurlinggesin as by die Blankegesin (Loubser, 1971, p.147).

- $\quad$ Armoede, alhoewel moeilik omlynbaar, raak byna die helfte van die Kleurlinggemeenskap, terwyl slegs $2 \%$ van die Blankegemeenskap daaronder gebuk gaan (Horner, 1972, p.11) en

- $\quad$ By die Kleurlinggemeenskap is $43 \%$ van alle geboortes buite-egtelik, terwyl dieselfde syfer by die Blankegemeenskap slegs $3 \%$ is (Theron-Kommissie, 1976, p.12).

Bogenoemde verskille in ontwikkelingspeil en sosio-ekonomiese posisie laat 'n sterk vermoede ontstaan dat die Kleurling, hoewel moontlik van dieselfde kultuurgroep as die Blanke, straks ander waardes en norme handhaaf sover dit materiële goedere (besonderlik geld) betref. 
Hierdie vermoede vorm dan ook die agtergrond waarteen hierdie ondersoek gedoen is. Meer eksplisiet gestel gaan dit dus in die ondersoek om die bepaling van differensiële betekenisse wat Blankes en Kleurlinge moontlik aan geld heg.

Vir hierdie doel is die volgende hipoteses geformuleer:

\section{HIPOTESE 1}

Daar bestaan geen beduidende verskil in die betekenis wat Blanke- en Kleurlingstudente aan die begrip geld heg nie.

\section{HIPOTESE 2}

Daar bestaan geen beduidende verskil tussen die (a) evaluasie-, (b) potensie-, en (c) aktiwiteitsdimensies van betekenis, vir Blanke- en Kleurlingstudente met betrekking tot geld nie.

\section{HIPOTESE 3}

Daar bestaan geen beduidende verskil tussen die beoordelings van afsonderlike semantiese skale vir die begrip geld, vir Blanke- en Kleurlingstudente nie.

\section{METODE EN NAVORSINGSTRATEGIE}

\section{Metingstegniek}

Daar is besluit om die semantiese differensiaal as meettegniek in hierdie navorsing te gebruik. Die semantiese differensiaal is 'n gekombineerde assosiasie- en skaaltegniek en word al die afgelope dertig jaar en meer vir betekenismeting gebruik (Osgood, 1976, p.3). 'n Beknopte uiteensetting van die rasionaal en werking van die semantiese differensiaal word in Kerlinger (1974, pp. 566-581) aangebied.

\section{Keuse van skale vir ondersoek}

Die skale wat in die semantiese differensiaal opgeneem is, is geselekteer uit onder andere die 50 basiese skale wat Osgood et al. (1957, p.37) gevind het om op die dimensies evaluasie, potensie en aktiwiteit betrekking te hê. Daar is egter ook van enkele ander skale, wat deur navorsers bevind is om op die betrokke dimensies te laai, gebruik gemaak. 
In die vraelys wat gebruik is, is daar van 7 evaluasie-, 4 potensie- en 4 aktiwiteitskale gebruik gemaak. Die skale, met die bron waaruit dit geselekteer is in hakies, word hieronder weergegee:

\section{Evaluasiedimensie}

Skaal: 1. Waardevol ------------Waardeloos*

2. Goed ------------------- Sleg*

3. Suksesvol ------------ Onsuksesvol (Nunnally, 1970, p.440)

4. Aangenaam ----------- Onaangenaam *

5. Regverdig ------------- Onregverdig*

6. Eerlik ------------------ Oneerlik*

7. Heilig ----------------- Onheilig*(Wernimont en Fitzpatrick, 1972, p.212)

\section{Potensiedimensie}

Skaal: 8. Sterk ----------------- Swak*

9. Rof -------------------- Fyn*

10. Manlik --------------- Vroulik (Nunnally, 1970, p.440)

(Wernimont et al., 1972, p.223)

11. Groot ---------------- Klein*

\section{Aktiwiteitdimensie}

Skaal: 12. Aktief Passief*

13. Gespanne ---------- Ontspanne (Nunnally, 1970, p.440)

14. Helder Dof*

15. Fluks Lui (Suci, in Snider en Osgood, 1969, p.285)

*Osgood et al., 1957, p. 37.

Die skale wat in die vraelys opgeneem is, skyn waarskynlik nie in alle gevalle toepaslik te wees nie. Tog moet die fynere nuanses van betekenisse nie uit die oog verloor word by die keuse van skale nie. Kerlinger (1973, p.571) beweer tereg dat skale nie altyd op sigwaarde beoordeel moet word nie aangesien betekenisse soms wyer strek as wat met die eerste oogopslag die geval blyk te wees. 


\section{Samestelling van die monster}

Vir die doeleindes van die studie is daar besluit om 300 Blanke- en Kleurlingstudente van die Universiteite van Stellenbosch en Wes-Kaapland te nader om die semantiese differensiaal te voltooi. Hierdie besluit is op grond van die volgende oorwegings geneem:

- Studente verteenwoordig gewoonlik die hoër sosio-ekonomiese gedeelte van 'n bevolkingsgroep, wat daartoe bydra dat hulle samestelling betreffende hul agtergrond tot 'n groter mate homogeen is. Ten opsigte van die Kleurlingstudent, is hierdie tendens ook deur die Theron-Kommissie (1976, p. 198) bevestig .

- As toekomstige sowel as huidige leierfigure behoort hierdie persone die sienswyses, norms en waardes van hulle gemeenskap pertiment uit te dra, sodat dit 'n goeie (hoewel soms ietwat idealistiese) weerspieëling is van hul onderskeie bevolkingsgroepe sin.

- Die Kleurlingstudent word in die meeste gevalle genoodsaak om na die Universiteit van Wes-Kaapland te gaan, sodat 'n monster wat daar onder studente geneem word moontlik 'n getroue weergawe van hul gemeenskap se waardes en norme sal reflekteer.

- $\quad$ Binnemuurse studente beskou geld meesal op 'n ideaal-wyse omdat min of geen studente hul "eie" geld verdien nie. Hulle oordeel daarvan word gevolglik nie soseer deur die werklikheid gekontamineer nie, en hulle is dus in staat om 'n gedistansieerde begrip daarvan te vorm - 'n begrip dus wat los staan van die verskeidenheid van persoonlike en dus individuele lastighede en probleme wat byvoorbeeld die broodwinner van 'n gesin sou ondervind.

Voorsorgmaatreëls is getref om die invloed van vreemde veranderlikes te verminder deur homogeniteit en ewekansigheid so ver as wat moontlik is in die monster in te "bou". Dit is op die volgende wyse gedoen:

Alhoewel studente tot 'n sekere mate alreeds uiteraard homogeen is, is daar in die monster, ter wille van hoër homogeniteit, slegs van binnemuurse studente gebruik gemaak. Verder, omdat 'n student se ouderdom ook die homogeniteit van die monster, vanweë die groeiproses (ontwikkelingsproses) en soms gepaardgaande hoër kwalifikasies, kan beïnvloed, is die maksimum ouderdom op 26 jaar gestel . Ewekansigheid is die sterkste voorsorgmaatreël wat teen die invloed van vreemde veranderlikes getref kan word. Om dié rede is die studente wat in elke monster opgeneem is, op 'n streng ewekansige basis gekies. By die Universiteit van Stellenbosch is die 150 binnemuurse studente ewekansig uit 'n moontlike 8000 met behulp van die rekenaar geselekteer. By die Universiteit van Wes-Kaapland is die 150 
binnemuurse studente uit 'n moontlike 2600 op 'n sistematiese ewekansige wyse volgens alfabetiese volgorde getrek.

Alvorens die vraelys op die Blanke- en Kleurlingstudente geadministreer is, is dit eers, om enige onduidelikheid daarin te bepaal, op 10 tweedejaar B.Comm.-studente van die Universiteit van Wes-Kaapland getoets. Geen onduidelikheid kon vasgestel word nie en die vraelys is daarna op die monster geadministreer.

\section{Versending van die vraelyste}

By die versending van vraelyste is gepoog om die foute wat moontlik in die beantwoording van die vraelys kon insluip as gevolg van reaktiewe meting en selfseleksie, te verminder.

Ten opsigte van reaktiewe meting is die vraelys wat versend is, anoniem behandel. Wat die adresse op die gefrankeerde koeverte betref, is daar 'n onderskeid tussen die twee studentegroepe gemaak. Vraelyste van Blankestudente moes na die Departement Bedryfsielkunde, Universiteit van Stellenbosch versend word, terwyl Kleurlingstudente hul vraelyste aan die Departement Sielkunde van die Universiteit van Wes-Kaapland moes terugstuur.

Daar is voorts gepoog om so min as moontlik selfseleksie toe te laat deur te verseker dat soveel as moontlik van die vraelyste terug ontvang word. Ten opsigte van die Blankestudente wat in die monster opgeneem is, was byna die helfte van die studente in Universiteitskoshuise gehuisves. In die geval van die koshuisstudente is daar op 'n onregstreekse wyse beheer oor die verspreiding en terugsending van die vraelyste uitgeoefen. By elke koshuis is 'n verantwoordelike verteenwoordiger, gewoonlik die primaria of primarius, versoek om toe te sien dat hul onderskeie koshuislede die vraelyste ontvang en ook weer versend.

Aangesien bogenoemde wyse van onregstreekse kontak met Kleurlingstudente en met Blankestudente wat nie in koshuise tuis was nie, vanweë praktiese redes nie wenslik was nie, is daar van 'n kodestelsel gebruik gemaak om te bepaal wie nie sy vraelys terugstuur nie. 'n Periode van tussen 2-3 weke is toegelaat voordat aan persone wat deur die kontrolelyste as die "sondebokke" aangedui is, weer 'n vraelys gepos is.

Van die 150 vraelyste wat aan elke groep versend is, is daar na drie maande 128 van die Blankegroep en 108 van die Kleurlinggroep terugontvang. 
Die data wat van die monsters verkry is, kan op twee wyses skematies voorgestel word. Eerstens kan die gegewens by wyse van 'n semantiese differensiaalprofiel (Nunnally, 1970,p.446) voorgestel word. Vir hierdie doel word die gemiddelde skaalwaardes vir elke groep bereken. Tweedens kan die betekenis, wat die begrip geld vir elke groep inhou, binne 'n geteoretiseerde semantiese ruimte voorgestel word. Vir hierdie doel moet die gemiddelde van al die skale wat op "n bepaalde dimensie (evaluasie, potensie of aktiwiteit) laai vir elke groep bereken word. Hierdie voorstellingswyses word in Figure 2 en 3 aangebied.

Skale

1. Waardevo1

2. Goed

3. Suksesvo1

4. Aangenaam

5. Regverdig

6. Eerlik

7. Heilig

8. Sterk

9. Rof

10. Manlik

11. Groot

12. Aktief

13. Gespanne

14. Helder

15. Fluks
Skaalbeoordelings
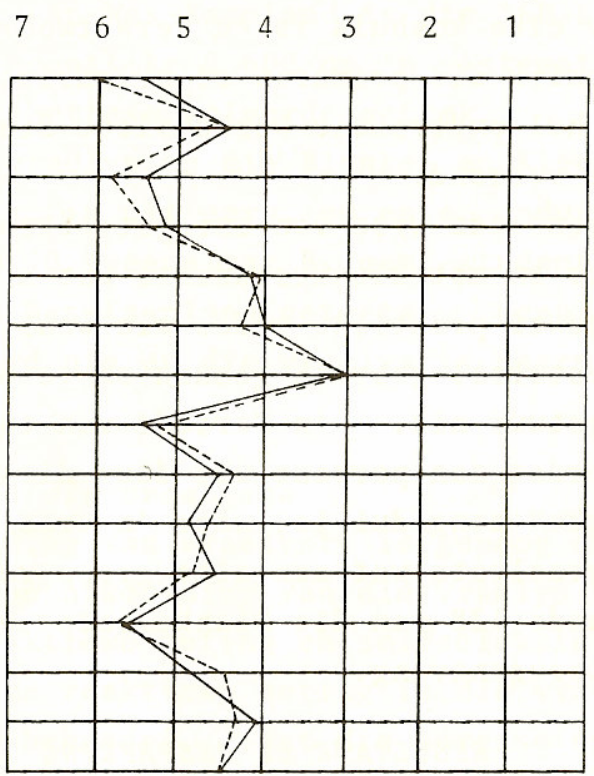

Waardeloos

Sleg

Onsuksesvo1

Onaangenaam

Onregverdig

Oneerlik

Onheilig

Swak

Fyn

Vroulik

Klein

Passief

Ontspanne

Dof

Lui

Skaalwaardes van Blankestudente

Skaalwaardes van Kleurlingstudente

Figuur 2: Die semantiese differensiaalprofiel ten opsigte van geld vir

Blanke- en Kleurlingstudente 


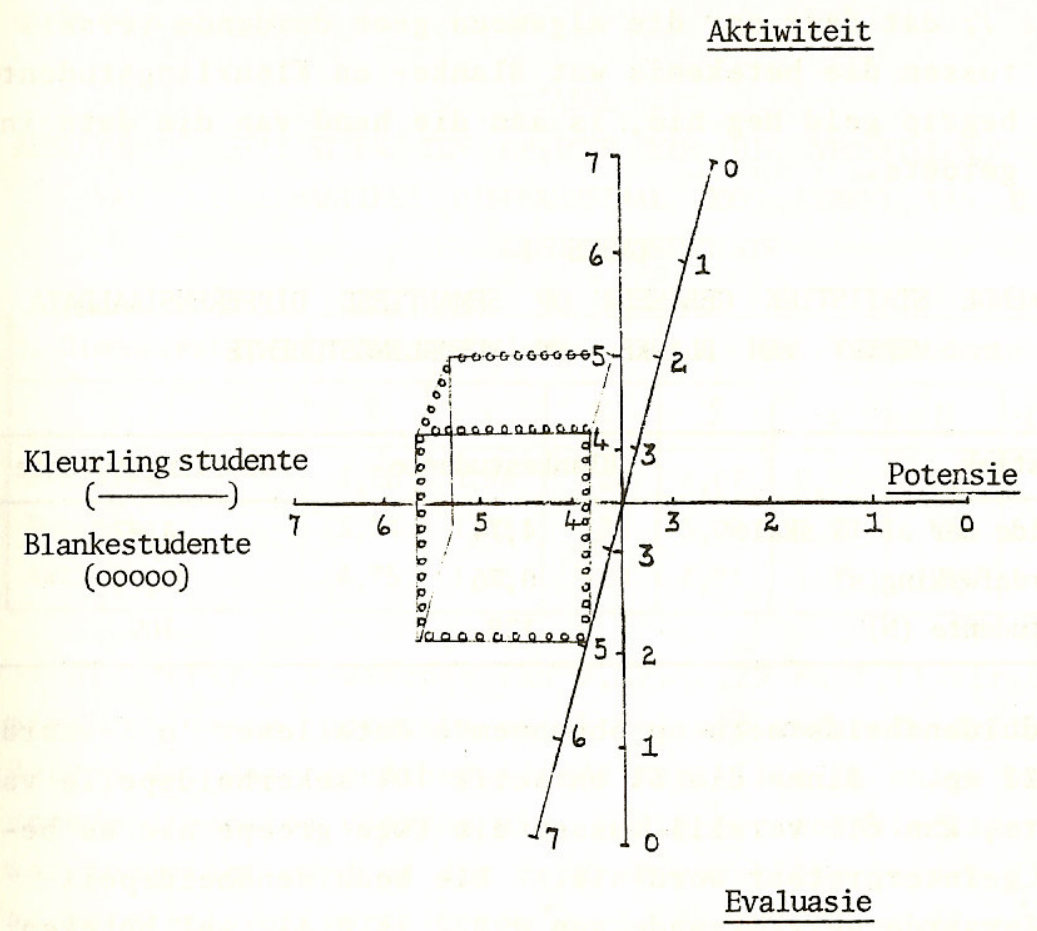

Figuur 3: Die betekenis van die begrip geld vir die Blanke- en Kleurlingstudent soos voorgeste1 binne die semantiese ruimte.

In figure 2 en 3 is dit duidelik (deur slegs op sigwaarde "n oordeel te vel) dat die betekenisse wat die Blanke- en Kleurlingstudente aan die begrip geld heg, baie na aan mekaar lê. Wat egter ook interessant is, is dat die verskillende fasette van die betekenis van geld van skaal tot skaal verskil en dat die groepe ooglopend saamstem ten opsigte van hierdie variasie.

Hipotese 1; dat daar oor die algemeen geen duidende verskil bestaan tussen die betekenis wat Blanke- en Kleurlingstudente aan die begrip geld heg nie, is aan die hand van die data in tabel 1 getoets.

\section{$\underline{\text { TABEL } 1}$}

BESKRYWENDE STATISTIEK GEBASEER OP SEMANTIESE DIFFERENSIAALDATA VERKRY VAN BLANKE- EN KLEURLINGSTUDENTE

\begin{tabular}{|lcc|}
\hline Statistiek & Blankestudente & Kleurlingstudente \\
\hline Gemiddelde oor al 15 skale & 4,74 & 4,82 \\
Standaardafwyking (s) & 0,76 & 0,73 \\
Getal studente (N) & 128 & 109 \\
\hline
\end{tabular}


'n Beduidendheidstoets op bogenoemde data lewer 'n Z-waarde van 0,822 op. Binne die $5 \%$ en selfs $10 \%$ sekerheidspeile van die toets, kan die verskil tussen die twee groepe nie as beduidend geïnterpreteer word nie. Die beduidendheidspeil van 'n Z-waarde gelykstaande aan 0,822 is 0,41 , wat beteken dat die aanvaarding van 'n beduidende verskil tussen die twee groepe 'n 41 persent "kans" vir 'n moontlike oordeelsfout toelaat. Statisties kan die verkreë verskil dus nie as beduidend vertolk word nie en daarom kan die nulhipotese nie op grond hiervan verwerp word nie.

Hipotese 2; dat daar geen beduidende verskil tussen die dimensies (evaluasie, aktiwiteit en potensie) wat die begrip geld by Blanke- en Kleurlingstudente openbaar, bestaan nie, is aan die hand van die data in tabel 2 aan 'n beduidendheidstoets onderwerp:

\section{TABEL 2}

\section{BESKRYWENDE STATISTIEK TEN OPSIGTE VAN DIE VERSKILLENDE DIMENSIES VAN DIE SEMANTIESE DIFFERENSIAAL SOOS VERKRY VAN BLANKE- EN KLEURLINGSTUDENTE}

\begin{tabular}{|l|c|cc|cc|cc|}
\hline Dimensies: & \multicolumn{3}{|c|}{ Blankestudente } & \multicolumn{4}{c|}{ Kleurlingstudente } \\
\hline & $\bar{X}$ & $\mathrm{~s}$ & $\mathrm{~N}$ & $\bar{X}$ & $\mathrm{~s}$ & $\mathrm{~N}$ & Z-waarde \\
\cline { 2 - 8 } Evaluasie & 4,56 & 0,98 & 128 & 4,67 & 0,97 & 109 & 0,865 \\
Potensie & 5,04 & 1,03 & 128 & 5,00 & 1,10 & 109 & 0,286 \\
Aktiwiteit & 4,75 & 1,16 & 128 & 4,91 & 1,05 & 109 & 1,110 \\
\hline
\end{tabular}

Die verkreë Z-waardes van 0,87, 0,29 en 1,11 vir die dimensies evaluasie, potensie en aktiwiteit onderskeidelik dui daarop dat daar geen beduidende verskille in enige van die genoemde dimensies voorkom nie. Die persentasie kans of fout wat toegelaat word as die verkreë verskille in die dimensies as betekenisvol vertolk sou word, is 38, 77 en 27 respektiewelik. Sover dit dus die evaluasie, potensie en aktiwiteitsbetekenis van geld aangaan blyk dit dat Kleurling- en Blankestudente dieselfde siening van geld het.

Hipotese 3; lui dat geen beduidende verskil tussen Kleurlinge en Blankes ten opsigte van 15 individuele skaalwaardes van die semantiese differensiaal voorkom nie. Aan die hand van die verkreë monsterdata is elke skaal gevolglik aan 'n beduidendheidstoets onderwerp. Die resultate word in tabel 3 aangedui. 


\section{TABEL 3}

BESKRYWENDE STATISTIEK EN Z-WAARDES TEN OPSIGTE VAN 15 SEMANTIESE SKALE SOOS VOLTOOI DEUR BLANKE- EN KLEURLINGSTUDENTE

\begin{tabular}{|c|c|c|c|c|c|c|c|}
\hline \multirow{2}{*}{ Skaal } & \multicolumn{3}{|c|}{ Blankestudente } & \multicolumn{3}{c|}{ Kleurlingstudente } & \multirow{2}{*}{ Z-Waarde } \\
\cline { 2 - 7 } & $\bar{X}$ & $\mathrm{~s}$ & $\mathrm{~N}$ & $\bar{X}$ & $\mathrm{~s}$ & $\mathrm{~N}$ & \\
\hline 1 & 5,48 & 1,63 & 128 & 6,09 & 1,34 & 109 & $3,148^{* *}$ \\
2 & 4,55 & 1,59 & 128 & 4,53 & 1,72 & 109 & 0,092 \\
3 & 5,34 & 1,62 & 128 & 5,36 & 1,51 & 109 & 0,098 \\
4 & 5,25 & 1,77 & 128 & 5,31 & 1,53 & 109 & 0,278 \\
5 & 4,15 & 1,85 & 128 & 4,09 & 1,84 & 109 & 0,248 \\
6 & 4,08 & 1,69 & 128 & 4,28 & 1,74 & 109 & 0,890 \\
7 & 3,04 & 1,57 & 128 & 3,05 & 1,51 & 109 & 0,050 \\
8 & 5,67 & 1,60 & 128 & 5,58 & 1,85 & 109 & 0,395 \\
9 & 4,77 & 1,76 & 128 & 4,64 & 1,78 & 109 & 0,561 \\
10 & 4,95 & 1,45 & 128 & 4,88 & 1,60 & 109 & 0,349 \\
11 & 4,79 & 1,87 & 128 & 4,88 & 1,93 & 109 & 0,361 \\
12 & 5,50 & 1,94 & 128 & 5,73 & 1,55 & 109 & 1,100 \\
13 & 4,97 & 1,98 & 128 & 4,80 & 1,83 & 109 & 0,683 \\
14 & 4,04 & 1,73 & 128 & 4,55 & 1,74 & 109 & $2,245^{*}$ \\
15 & 4,50 & 2,11 & 128 & 4,54 & 1,88 & 109 & 0,154 \\
\hline
\end{tabular}

Volgens tabel 3 skyn daar wel beduidende verskille ten opsigte van skale 1 en 14 te wees. Die verkreë verskil ten opsigte van skaal 1 kan as redelik groot bestempel word. Die waarskynlikheid dat hierdie verskil as gevolg van 'n fout of toeval veroorsaak is, is gelykstaande aan 0,002 uit 'n 100 of 0,2 persent. Ten opsigte van skaal 14, is hierdie waarskynlikheid ietwat groter, (nl. 0,024 uit 'n 100) maar kan nog steeds as hoogs beduidend beskou word. Die nulhipotese van geen verskille tussen die semantiese skaalwaardes tussen die twee groepe moet dus verwerp word. In die plek daarvan word 'n alternatiewe hipotese voorlopig aanvaar, naamlik dat daar wel in sommige semantiese skaalwaardes beduidende verskille tussen Blanke- en Kleurlingstudente voorkom.

Indien na 'n verklaring vir die beduidende verskille ten opsigte van skale 1 en 14 gesoek word, kan dit moontlik gevind word in die per kapita inkomsteverskille (sakgeld) tussen die twee groepe. Soos vroeër aangedui, is die ekonomiese posisie van die Blanke gemiddeld heelwat beter as die van die Kleurling, sodat daar verwag kan word dat weens die laer per kapita inkomste (sakgeld) van Kleurlingstudente, hulle waardering van geld (Skaal 1:

Waardevol - waardeloos/Skaal 14: helder - dof) moontlik hoër/positiewer mag wees - dit word 
ook binne die ekonomiese teorie verklaar deur die grensnut wat aan geld verbonde is (De Reville, 1970, p.63).

Dit is voorts opmerklik dat die minste meningsverskil (gemeet aan die standaardafwykings van skaalbeoordelings) ten opsigte van skaal 1 (Waardevol - Waardeloos) by Kleurlingstudente voorgekom het. Hierdie resultate beklemtoon opnuut weer die eenstemmigheid ten opsigte van die waarde van geld vir die groep. Dit is miskien ook teen dié agtergrond te verstane waarom geld vir Kleurlingstudente 'n helderder beeld (skaal 14) as vir Blankes vorm.

Hierdie resultate stem tot 'n mate ooreen met die studie van Bruner en Goodman (Lindgren et al., 1971, 239) waar daar bevind is dat die hoër waarde wat behoeftiger skoliere aan geld heg, veroorsaak dat die grootte van muntstukke oorskat word.

\section{GEVOLGTREKKING}

Die ondersoek toon aan dat geld nie slegs 'n monetêre middel is wat materiële welvaart aandui nie, maar dat dit 'n dieper en enger betekenis vir mense inhou. Dit is derhalwe vir bedryfsielkundiges en ander gedragwetenskaplikes noodsaaklik om die betekenis daarvan te peil, aangesien die betekenis van begrippe dikwels belangrike bepalers van gedrag kan wees.

Waar die agtergrond van persone aansienlik van mekaar verskil, kan redelikerwys verwag word dat die betekenis wat aan dieselfde begrippe geheg word, sal verskil. Inligting wat uit die ondersoek verkry is, dui egter daarop dat die betekenis van geld, soos deur die semantiese differensiaal gemeet, oor die algemeen vir Blanke- en Kleurlingstudente dieselfde is alhoewel sekere skale in die ondersoek verskille in die kleine aangedui het.

Die gedagtegang dat Blankes en Kleurlinge 'n totaal verskillende kulturele agtergrond het en daarom 'n heeltemal anderse waardesisteem moet hê, skyn volgens die bevindinge van die ondersoek 'n oorvereenvoudiging te wees. Waar die hoër opvoedkundige en intellektuele vlak van die genoemde identiteitsgroepe met mekaar vergelyk word, stem die waardes en norms van die twee groepe tot 'n groot mate ooreen.

Dit wil dus voorkom asof die betekenis wat aan geld geheg word deur Blankes en Kleurlinge wat min of meer dieselfde vlak van ontwikkeling bereik het, grotendeels ooreen stem. Hierdie bevinding bevraagteken op sigself die lang vertroetelde gedagte (veralge- 
mening) dat Nie-Blankes, as 'n groep, gewoonlik nie " die waarde van geld" besef nie en gevolglik nie, in finansiële terme, oor dieselfde kam as Blankes geskeer kan word nie.

Ten slotte dien die aandag egter weer eens daarop gevestig te word dat die monster uit studentepopulasies getrek is en dat die bevindings van hierdie studie op Blankes en Kleurlinge in die algemeen van toepassing is slegs tot die mate waartoe studente in die algemeen verteenwoordigend is van hul onderskeie gemeenskappe.

\section{OPSOMMING}

'n Oorsig van relevante literatuur dui daarop dat die betekenis van geld (wat' $n$ belangrike plek in sekere motiveringsteorië inneem) van persoon tot persoon kan verskil. Hierdie verskil kan hoofsaaklik aan persoonlike- en agtergrondsfaktore toegeskryf word. Wanneer die genoemde faktore binne groepsverband ooreenstem, ontwikkel en vorm daar unieke "groepsbetekenisse" wat aan sekere begrippe geheg word. Betekenismeting wat in hierdie ondersoek deur middel van die semantiese differensiaal op 128 Blanke- en 109 Kleurlingstudente uitgevoer is, toon egter oor die algemeen geen beduidende verskil ten opsigte van die begrip geld nie. Slegs ten opsigte van twee van 15 semantiese skale is beduidende verskille tussen die twee groepe gevind.

\section{VERWYSINGS}

Backer, W. Black Motivation: What has the Herzberg model taught us? People and Profits, 1974, 2, (9), 19-31.

Cilliers, S.P. Appeal to Reason. Stellenbosch, U.U.B., 1971.

De Reville, M.J.C. Mikro-Ekonomie. Stellenbosch. Kosmo, 1970.

Dyal, J.A. Readings in Psychology: Understanding Human Behavior. New York: McGrawHill, 1962.

Theron, Erika. Kommissie van Ondersoek na die Aangeleenthede Rakende die Kleurlingbevolkingsgroep. Kaapstad. 1976.

Feldsman, J.M. Race, Employment and the Evaluation of Work. Journal of Applied Psychology. 1973 (a), 58, (1), 1-10.

Feldsman, J.M. Race, Economic Class and Perceived Outcomes of Work and Unemployment. Journal of Applied Psychology. 1973 (b), 58, (1) 16-22.

Harris, F. Motivation of Coloured Workers. Referaat gelewer tydens I P B Konferensie, Johannesburg, Maart 1974.

Hewitt, C.B. Factors Affecting the Work Motivation of Bantu Mineworkers. Pretoria. Ongepubliseerde M.A.-Verhandeling. UNISA, 1976.

Horner, J.A. Non-White Pay and Productivity in South Africa. Personeelbestuur, 1972, 23, 4, 9-16.

Kerlinger, F.N. Foundations of Behavioral Research. New York: Holt, 1973. 
Lindgren, H.V. \& Byrne, D. Psychology: An Introduction to a Behavioral Science. New York: Wiley, 1971.

Loubser, M. The market potential of consumer goods in selected urban areas of the Republic of South Africa. Finance and Trade Review, 1971, 10, (1), 163-220.

Nunnally, J.C. Psychometric Theory. New York: McGraw-Hill, 1967.

Nunnally, J.C. Introduction to Psychological Measurement. New York: McGraw-Hill, 1970.

Orpen, C. How a study of 250 Blacks in 10 factories put Herzberg-type motivation in nonwhite perspective. Management, 1974, Maart, 64-67.

Orpen, C. The limitations of the motivator-hygiene theory of satisfaction: An empirical study with Black factory workers in South Africa. Journal of Behavioural Science, 1975, 2, (3), 137-149.

Osgood, C.E. The measurement of meaning. Urbane: Illinois, 1957.

Osgood, C.E. Focus on Meaning, Volume: Explorations in Semantic space. Holland, Mouton, 1976.

Snider, J.G. and Osgood, C.E. Semantic differential technich. New York: Aldine, 1969.

Suci, G.J. \& Tannenbaum, P.H. The measurement of meaning. Urbana; Illinois: 1957.

Porter, L.W., Lawler, E.E. \& Hackman, J.R. Organizational Behavior. New York, McGrawHill, 1975.

Price-Williams, D.R. Cross-cultural Studies. Middlesex. Penguin, 1967.

Van Eeden, D.J. Evaluering van die Herzberg-model - 'n Studie oor Motivering en 'n Ondersoek onder Kleurlingarbeiders in 'n Suid-Afrikaanse Onderneming. Stellenbosch; Ongepubliseerde M.Comm.-verhandeling, U.S. 1974.

Van der Walt, J.A., Maritz, F.A. en Strauss, J. Rassesosiologie. Kaapstad: Academia, 1967.

Wernimont, P.F. \& Fitzpatrick, S. The meaning of money. Journal of Applied Psychology. 1972, 36, 218-226. 